\title{
The Association between Internal Control Situations and Specialist Auditor Choices
}

\author{
Ya-Fang Wang ${ }^{1} \&$ Yu-Ting Huang ${ }^{2}$ \\ ${ }^{1}$ Department of Accounting, Providence University, Taichung, Taiwan \\ ${ }^{2} \mathrm{Ph}$. D. Program in Business, Chung Yuan Christian University, Chung Li, Taiwan \\ Correspondence: Ya-Fang Wang, Department of Accounting, Providence University, Taichung, Taiwan. Tel: \\ 886-4-2632-8001 ext. 13216. E-mail: yfwang2@pu.edu.tw
}

\author{
Received: April 21, 2013 \\ Accepted: May 3, 2013 \\ Online Published: May 17, 2013 \\ doi:10.5539/ibr.v6n6p75 \\ URL: http://dx.doi.org/10.5539/ibr.v6n6p75
}

\begin{abstract}
This investigation sought to uncover empirical results of the influence of internal control quality on the probability of auditor turnover. Our findings show that the probability of auditor termination significantly increases for companies with material deficiencies in their internal control system. We also discovered that such companies are less likely to hire auditors specializing in a particular industry. Finally, our results demonstrate that companies with material deficiencies in their internal control system are more likely to pay higher audit fees when hiring specialist auditors in order to restore their internal control system.
\end{abstract}

Keywords: internal control, restatement, specialist auditor, audit fees

\section{Introduction}

Section 404 mandates that all publicly-traded companies must establish internal controls and procedures for financial reporting and must document, test, and maintain those controls and procedures to ensure their effectiveness. The purpose of Section 404 is to reduce the possibility of corporate fraud by increasing the stringency of procedures and requirements for financial reporting. Following the passage of the Sarbanes-Oxley Act (SOX) of 2002, all SEC registrants are required to comply with Section 404 regarding the public disclosure of material deficiencies in internal control system. All deficiencies in internal control system discovered during managerial evaluation and auditing processes must be reported to the SEC. Regulators intended that the disclosure of material deficiencies in internal control system would give the users of financial statements with an early warning sign of potential problems related to the quality of financial statements. Under Section 404, management and auditors play crucial roles in the internal control of financial statements with the aim of maintaining the credibility of financial reports and investor confidence in capital markets.

Internal control systems are the first line of defense protecting the quality of financial statements. External auditors provide the second line through their assessment of internal controls to determine the reliability of accounting systems. The Enron bankruptcy is a case of failure in internal control and auditing. Despite many material deficiencies in internal control system, the engagement partner wrote that Andersen's work would "consist of an examination of management's assertion that the system of internal control of Enron as of December 31, 2000, was adequate to provide reasonable assurance as to the reliability of financial statements." Current research tends to focus on the underlying causes of deficiencies in internal control system (Hammersley et al., 2008; Doyle et al., 2007b; Krishnan \& Visvanathan, 2007; Ashbaugh-Skaife et al., 2007) and the consequences of internal control failure (Elder et al., 2009; Hoitash et al., 2008; Hoitash et al., 2007; Hogan \& Wilkins, 2008; Raghunandan \& Rama, 2006). Nonetheless, no systematic evidence has been found regarding the association between internal control situations and external auditor selections.

This study examines three important issues regarding the association between internal control situations and external auditor selections. Considering that internal control failures are frequently triggered by changes in auditor, this study sought to determine whether the internal control situations affect the decision of auditor changes, the choice of auditors, and audit fees. Our results provide evidence that the probability of changes in auditors is significantly higher in companies with material deficiencies in internal control system. Specifically, post-SOX restatements significantly affect the association between the probability of changes in auditors and 
material deficiencies in internal control system. Companies with material deficiencies in internal control system that replace an auditor are unlikely to hire specialist auditors. We also provide empirical evidence that companies hiring specialist auditors to restore internal control quality are likely to pay higher than average audit fees. By extending prior empirical findings on the relationship between internal control and auditor selection, our findings contribute to the existing literature as one of the few studies documenting this relationship, and that between audit fees and auditor selections.

The remainder of this paper is organized as follows. Section 2 discusses previous relevant studies. Section 3 describes our research samples and research models. Section 4 presents the empirical results while Section 5 provides conclusions.

\section{Literature Review}

Internal controls are developed by companies to safeguard their assets and produce accurate, reliable financial statements. Companies lacking strong internal control system are unable to reveal problematic areas or risk. As a result, Section 404 requires that management issue in their annual statements an assessment of the structure and operating effectiveness of their internal control system which is then evaluated by external auditors. Deficiencies in policies, procedures, or the fulfillment of the internal control framework are referred to as internal control weaknesses.

Doyle et al. (2007b) indicated that a quality internal control system is provides the foundation for quality financial reporting, due to its ability to curtail procedural and measurement errors as well as earnings manipulation. Previous studies (Romanus et al., 2008; Lazer et al., 2004; Lys \& Watts, 1994) have examined the relationships among internal control system, financial quality, and external auditors, focusing on the negative consequences of disclosing material deficiencies in internal control system. In contrast, this study investigates the relationship between internal control situations and external auditor selections by examining whether companies with internal control deficiencies are more likely to terminate their incumbent auditors, particularly when restatements are perceived as salient. Thus, we examined whether these companies incurring the seriousness of restatements are more likely to terminate incumbent auditors with the aim of providing investors with a useful and timely reference.

We also examined the process of auditor selection itself because of its effect on the demand for specialist auditors. For example, a change in auditor of companies' internal control systems downgrade from quality internal control to weak internal control, the demand of specialist auditor could be decreasing. We conjecture that specialist auditors are less likely to be engaged following the disclosure of material deficiencies in their internal control system and incurring the seriousness of restatements afterword, for fear of raising questions regarding the motivation of management. Therefore, this study examined whether differences in internal control system affect the demand for industry specific auditing services.

Under Auditing Standard No. 2 and Section 404, the effort required by audits of internal control is substantially greater than the effort traditionally required for consideration of internal control solely in connection with audits of financial statements, and much of the debate regarding the high costs of Section 404 is centered on audit fees. Previous research (Ferguson et al., 2006; Francis et al., 2005) indicated that large auditing firms and specialist auditors deliver higher audit quality and charge higher fees. Therefore, companies with internal control deficiencies are likely to be less profitable and less likely to pay higher fees in order to engage specialist auditors. If these companies do hire a specialist auditor, they may be forced to pay higher audit fees than companies with sound internal controls.

\section{Research Design}

\subsection{Data and Sample Selection}

Data was drawn from publicly listed companies in U.S. between November 2004 and December 2005, using the OLS and probit models. To control for sample homogeneity, obey the SEC disclosure rules, and avoid exchange-market effects, research observations were limited to companies listed on the NASDAQ, NYSE, and AMEX. This study identified material deficiencies in internal control system by searching for SEC filings (e.g., $10-\mathrm{K} / \mathrm{A}, 10-\mathrm{K}$, etc.) to assure disclosure of any material deficiencies in internal control system. Moreover, we used the search term "did not maintain effective internal control" to identify material deficiencies in internal control system (DEKP 2004) common in auditing reports. We sifted through data on the dates of first restatement announcements from the Lexis-Nexis News Library, which covers all interim and annual restatements announced from November 2004 through December 2005. Additionally, company's financial data was obtained from the Standard and Poor's COMPUSTAT database. This database lists most of the variables important to this 
avenue of investigation.

\subsection{Research Models}

In the following section, we present three regression models: (1) to examine the association between internal control situations and auditor changes; (2) to test whether companies with weak internal controls are less likely to hire a specialist auditor; and (3) to test whether the association between audit fees and auditor industry specialization varies according to the quality of internal controls.

$$
\begin{gathered}
C H A N G E=\alpha_{0}+\alpha_{1} I C W+\alpha_{2} S A L E G R W+\alpha_{3} L E V+\alpha_{4} L O S S+\alpha_{5} R O A+\alpha_{6} Q U I C K+\alpha_{7} C A T A+\alpha_{8} C F O+\varepsilon \\
\text { EXPERT }=\alpha_{0}+\alpha_{1} C H A N G E+\alpha_{2} S A L E G R W+\alpha_{3} L E V+\alpha_{4} L O S S+\alpha_{5} R O A+\alpha_{6} Q U I C K+\alpha_{7} C A T A+\alpha_{8} C F O+\varepsilon \\
A F F=\alpha_{0}+\alpha_{1} E X P E R T+\alpha_{2} S A L E G R W+\alpha_{3} L E V+\alpha_{4} L O S S+\alpha_{5} R A+\alpha_{6} Q U I C K+\alpha_{7} C A T A+\alpha_{8} M A \\
+\alpha_{9} L S U B+\alpha_{10} C F O+\varepsilon
\end{gathered}
$$

where

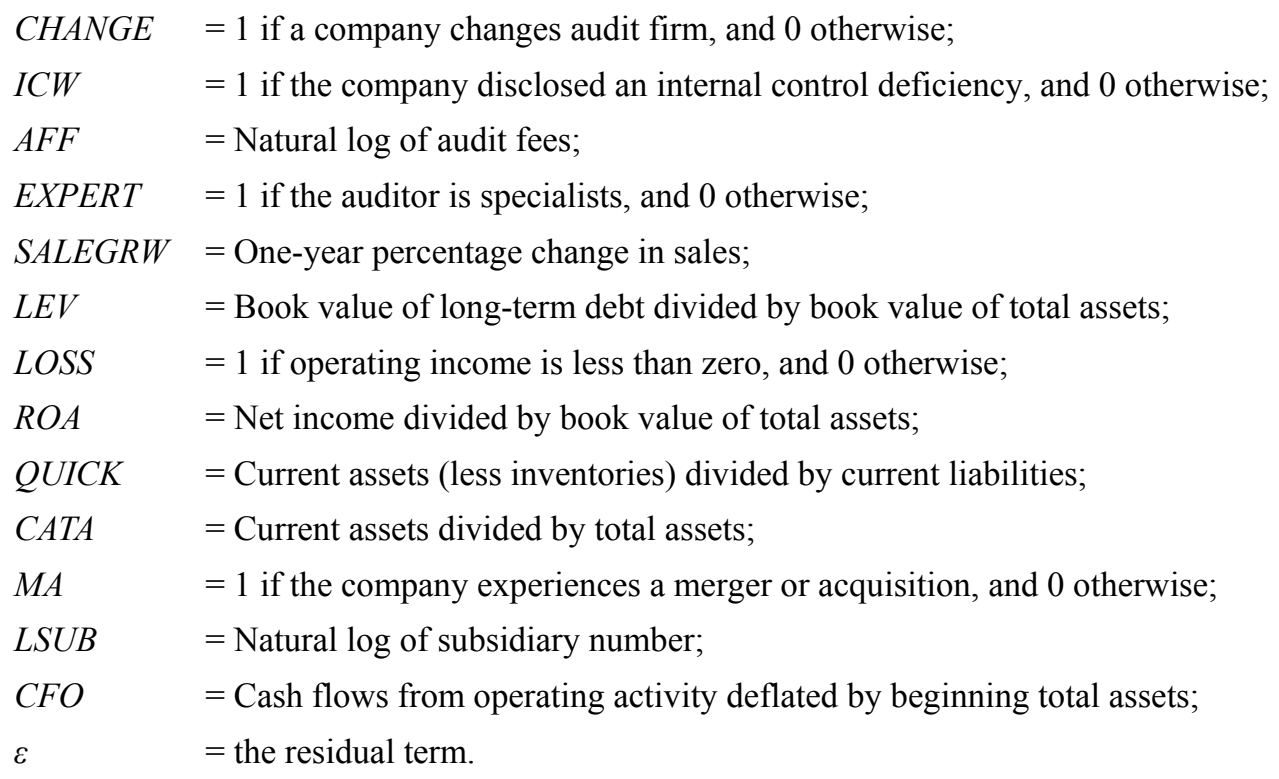

CHANGE is an indicator variable equals to 1 if a company changes its auditing firm, and 0 otherwise. $I C W$ is an indicator variable equals to 1 if the company disclosed an internal control deficiency, and 0 otherwise (Ge \& McVay, 2005; Doyle et al., 2007a; Doyle et al., 2007b). AFF measures indicates the audit fees (Ferguson et al., 2006; Francis et al., 2005). EXPERT is an indicator variable equals to 1 if the auditors are specialists (Balsam et al., 2003; Krishnan, 2003; Francis et al., 2005). This study selected control variables based on prior research regarding the factors most likely to be associated with our research models. We controlled for operational complexity (MA, LSUB and CFO) and financial condition (SALEGRW, LEV, LOSS, ROA, QUICK and CATA).

\section{Empirical Results}

\subsection{Descriptive Statistics}

Panel A of Table 1 presents the descriptive statistics for all variables used in our analysis, partitioned into three subsamples: total research samples $(\mathrm{n}=356)$, companies with $(\mathrm{n}=130)$, and without $(\mathrm{n}=226)$ internal control deficiencies. The results show that the mean (median) values of CHANGE and AFF reported in the subsample with material deficiencies is larger than those reported in the subsample without material deficiencies. Moreover, the mean (median) values for EXPERT in the subsample with material deficiencies are smaller than those reported in the subsample without material deficiencies. These findings suggest that companies with material deficiencies in internal control system are more likely to be associated with auditor termination, non-specialist auditors, and higher audit fees. Panel B of Table 1 presents the pairwise Pearson and Spearman correlations for control variables used in the research models. Most of these control variables are not significantly correlated to one another. We also computed the variance inflation factors (VIFs), none of which was greater than 3, suggesting that our empirical results are not affected by multicollinearity (Kennedy 1998).

\subsection{Changes in Auditor and Material Deficiencies in Internal Control System}

To examine the association between the probability of auditor turnover and material deficiencies in internal 
control system, we regressed the internal control variable and control variables related to auditor changes using the probit model. Table 2 presents estimates from a probit regression of model (1). Consistent with our expectation, in column (1), the coefficient of ICW is 0.40 (significant at $p<0.05$ ), indicating that an auditor is more likely to be terminated if the internal control system of the restating company involved material deficiencies. To explore the relationship between auditor changes and material deficiencies in internal control system in different research samples, we partitioned the sample into two groups: pre-SOX misstatements of post-SOX restatements, and post-SOX misstatements of post-SOX restatements. In column (2), the coefficient of ICW is insignificantly positive whereas the coefficient on ICW in column (3) is significantly positive $(p<0.05)$. These results indicate that companies with deficiencies in internal controls are more likely to terminate their auditors, particularly when they involve post-SOX misstatements of post-SOX restatements. Post-SOX misstatements of post-SOX restatements imply that companies do not comply with requirements of the SOX, which leads to restatements regarding financial statements issued after SOX. Overall, our findings are consistent with the issue that companies with material deficiencies in internal control system are more likely to terminate their auditors, particularly when post-SOX restatements are perceived as salient.

Table 1. Descriptive statistics $(\mathrm{n}=356)$

\begin{tabular}{|c|c|c|c|c|c|c|c|c|c|}
\hline \multirow[b]{2}{*}{ Variables } & \multicolumn{3}{|c|}{ Total sample $(\mathrm{n}=356)$} & \multirow{2}{*}{$\begin{array}{l}\text { Internal } \\
(\mathrm{n}=130)\end{array}$} & \multicolumn{2}{|l|}{ control } & \multicolumn{3}{|c|}{$\begin{array}{l}\text { No internal control deficiencies } \\
(\mathrm{n}=226)\end{array}$} \\
\hline & Mean & \multicolumn{2}{|c|}{ Median } & & \multicolumn{2}{|c|}{ Median } & Mean & \multicolumn{2}{|c|}{ Median } \\
\hline CHANGE & 0.1067 & \multicolumn{2}{|c|}{0.0000} & 0.1615 & \multicolumn{2}{|c|}{0.0000} & 0.0752 & \multicolumn{2}{|c|}{0.0000} \\
\hline EXPERT & 0.7275 & \multicolumn{2}{|c|}{1.0000} & 0.7000 & \multicolumn{2}{|c|}{1.0000} & 0.7434 & \multicolumn{2}{|c|}{1.0000} \\
\hline$A F F$ & 14.6391 & \multicolumn{2}{|c|}{14.5238} & 14.7620 & \multicolumn{2}{|c|}{14.5755} & 14.5684 & \multicolumn{2}{|c|}{14.4970} \\
\hline SALEGRW & 0.1337 & \multicolumn{2}{|c|}{0.0973} & 0.1310 & \multicolumn{2}{|c|}{0.0866} & 0.1352 & \multicolumn{2}{|c|}{0.1018} \\
\hline$L E V$ & 0.2092 & \multicolumn{2}{|c|}{0.1469} & 0.1636 & \multicolumn{2}{|c|}{0.0928} & 0.2355 & \multicolumn{2}{|c|}{0.1644} \\
\hline LOSS & 0.2697 & \multicolumn{2}{|c|}{0.0000} & 0.4077 & \multicolumn{2}{|c|}{0.0000} & 0.1903 & \multicolumn{2}{|c|}{0.0000} \\
\hline$R O A$ & 0.0133 & \multicolumn{2}{|c|}{0.0379} & -0.0216 & \multicolumn{2}{|c|}{0.0125} & 0.0333 & \multicolumn{2}{|c|}{0.0449} \\
\hline QUICK & 1.7468 & \multicolumn{2}{|c|}{1.1380} & 1.6788 & \multicolumn{2}{|c|}{1.1843} & 1.7859 & \multicolumn{2}{|c|}{1.1036} \\
\hline CATA & 0.4583 & & & 0.5103 & & & 0.4285 & & \\
\hline$M A$ & 0.1348 & & & 0.1154 & & & 0.1460 & & \\
\hline$L S U B$ & 0.7583 & & & 0.7287 & & & 0.7753 & & \\
\hline$C F O$ & 0.0887 & & & 0.0641 & & & 0.1029 & & \\
\hline Panel B : C & lation matrix & & & & & & & & \\
\hline & $S A L E G R W$ & $L E V$ & LOSS & $R O A$ & QUICK & CATA & $M A$ & $L S U B$ & $C F O$ \\
\hline SALEGRW & & -0.044 & $-0.173 *$ & $0.212 *$ & 0.063 & 0.061 & $0.157^{*}$ & -0.094 & $0.287^{*}$ \\
\hline$L E V$ & $0.200 *$ & & $0.187^{*}$ & $-0.277^{*}$ & $-0.225^{*}$ & $-0.514 *$ & $0.151^{*}$ & $0.116^{*}$ & $-0.156^{*}$ \\
\hline LOSS & -0.086 & $0.216^{*}$ & & $-0.769^{*}$ & 0.048 & $0.105^{*}$ & 0.038 & -0.006 & $-0.593 *$ \\
\hline$R O A$ & $0.205^{*}$ & -0.102 & $-0.615^{*}$ & & -0.001 & 0.002 & -0.062 & -0.097 & $0.706^{*}$ \\
\hline QUICK & $0.116^{*}$ & -0.044 & 0.068 & 0.006 & & $0.354^{*}$ & 0.036 & 0.059 & $-0.111^{*}$ \\
\hline CATA & 0.066 & $-0.407^{*}$ & $0.113 *$ & -0.092 & $0.320^{*}$ & & $-0.104 *$ & -0.085 & $-0.186^{*}$ \\
\hline$M A$ & $0.139 *$ & $0.201 *$ & 0.038 & -0.007 & -0.013 & -0.099 & & 0.044 & 0.071 \\
\hline$L S U B$ & $-0.114^{*}$ & 0.0133 & -0.010 & 0.018 & -0.011 & -0.087 & 0.054 & & $-0.149 *$ \\
\hline $\mathrm{CFO}$ & $0.259 *$ & $-0.108^{*}$ & $-0.540 *$ & $0.742 *$ & -0.059 & $-0.202^{*}$ & 0.057 & -0.050 & \\
\hline
\end{tabular}

Notes: ${ }^{1}$ Pearson correlations in the lower diagonal and Spearman correlations in the upper diagonal. * Indicates significance at the 5 percent level. 
Table 2. Auditor change and internal control deficiency

\begin{tabular}{|c|c|c|c|c|c|c|c|}
\hline \multirow[b]{3}{*}{ Variables } & \multirow[b]{3}{*}{ Pred. Sign } & \multirow{2}{*}{\multicolumn{2}{|c|}{$\begin{array}{c}(1) \\
\text { Total smaple }\end{array}$}} & \multirow{2}{*}{\multicolumn{2}{|c|}{$\begin{array}{c}(2) \\
\text { Post-Pre }^{1}\end{array}$}} & \multicolumn{2}{|c|}{ (3) } \\
\hline & & & & & & \multicolumn{2}{|c|}{ Post-Post } \\
\hline & & Coef. & $z$-value ${ }^{2}$ & Coef. & $z$-value & Coef. & $z$-value \\
\hline CONSTANT & & -2.1181 & $-5.54 * * *$ & -1.8426 & $-2.67 * * *$ & -2.1173 & $-5.52 * * *$ \\
\hline$I C W$ & + & 0.4035 & $2.01 * *$ & 0.3089 & 0.91 & 0.4100 & $2.04 * *$ \\
\hline$S A L E G R W$ & $?$ & -0.6578 & -1.23 & -0.8927 & -0.88 & -0.6703 & -1.25 \\
\hline$L E V$ & $?$ & -0.3382 & -0.55 & -1.2881 & -0.88 & -0.3471 & -0.56 \\
\hline LOSS & $?$ & 0.0346 & 0.12 & 0.0958 & 0.17 & 0.0634 & 0.21 \\
\hline$R O A$ & $?$ & 1.1050 & 0.97 & 1.5905 & 0.58 & 1.1564 & 1.01 \\
\hline QUICK & $?$ & 0.0105 & 0.28 & -0.0735 & -0.65 & 0.0100 & 0.27 \\
\hline CATA & $?$ & 1.6087 & $2.87 * * *$ & 1.7534 & $1.91 * *$ & 1.6007 & $2.85^{* * *}$ \\
\hline$C F O$ & $?$ & -0.5848 & -0.52 & -1.8442 & -0.79 & -0.5706 & -0.51 \\
\hline Pseudo $\mathrm{R}^{2}$ & & $10.62 \%$ & & $13.86 \%$ & & $10.70 \%$ & \\
\hline Nobs. & & 356 & & 131 & & 353 & \\
\hline
\end{tabular}

\subsection{Specialist Auditor Selection and Auditor Change}

As mentioned above, companies with material deficiencies in internal control system are more likely to terminate their auditors. In this section, we look at the means by which these companies select new auditors. Table 3 lists the results of the probability of hiring specialist auditors regressed on changes in auditors. We then explored the relationship between the probability of hiring specialist auditors and changes in auditors in different sample groups. As previously, the sample was partitioned into two groups: pre-SOX misstatements of post-SOX restatements, and post-SOX misstatements of post-SOX restatements. Column (1) of Table 3 shows that the coefficient of CHANGE is significantly negative $(p<0.01)$. The coefficient of CHANGE in column (2) is insignificantly negative whereas the coefficient of CHANGE in column (3) is significantly positive $(p<0.01)$. These findings indicate that when auditors are terminated by restating companies with internal control deficiency, the company is less likely to hire specialists as their new auditors, particularly when these restating companies with internal control deficiency involve post-SOX misstatements of post-SOX restatements.

\subsection{Audit Fees and the Selection of Specialist Auditors}

As mentioned above, if restating companies with internal control deficiency involves post-SOX misstatements of post-SOX restatements, it is less likely that specialist auditors will be hired following auditor termination. Nonetheless, if these companies did hire a specialist as the new auditor, it is important to determine whether specialist auditors would charge higher audit fees than they would for companies without material deficiencies in internal control system. Thus, we focused on post-SOX misstatements of post-SOX restatements and examined the association between audit fees and auditor choices in companies with material deficiencies in internal control system. Column (1) of Table 4 shows that the coefficient of EXPERT is significantly positive $(\mathrm{p}<0.01)$, suggesting that specialist auditors charge high audit fees for companies with post-SOX misstatements of post-SOX restatements. We partitioned the sample into two groups: companies with and without material deficiencies in internal control system. Empirical results show that the coefficient of EXPERT in column (2) is significantly positive $(\mathrm{p}<0.01)$, and the coefficient of EXPERT in column $(3)$ is marginally significant $(\mathrm{p}<$ 0.10 ). These results suggest that audit fees are significantly higher for companies with post-SOX misstatements of post-SOX restatements, particularly when the internal control system of these companies is deficient. 
Table 3. Specialist auditor choice and auditor change

\begin{tabular}{|c|c|c|c|c|c|c|c|}
\hline \multirow[b]{3}{*}{ Variables } & \multirow[b]{3}{*}{ Pred. Sign } & \multicolumn{2}{|c|}{ (1) } & \multicolumn{2}{|c|}{ (2) } & \multicolumn{2}{|c|}{ (3) } \\
\hline & & \multicolumn{2}{|c|}{ Internal control deficiencies } & \multicolumn{2}{|c|}{ Post-Pre $^{1}$} & \multicolumn{2}{|c|}{ Post-Post } \\
\hline & & Coef. & $z$-value ${ }^{2}$ & Coef. & $z$-value & Coef. & $z$-value \\
\hline CONSTANT & & 0.6781 & 1.58 & 1.4961 & $1.71^{*}$ & 0.7240 & $1.67 *$ \\
\hline CHANGE & - & -0.8781 & $-2.69 * * *$ & -0.4762 & -0.90 & -0.9229 & $-2.79 * * *$ \\
\hline$S A L E G R W$ & $?$ & -0.2428 & -0.39 & -0.1048 & -0.09 & -0.2510 & -0.40 \\
\hline$L E V$ & $?$ & 1.0290 & 1.32 & -0.3691 & -0.24 & 0.9012 & 1.41 \\
\hline LOSS & $?$ & 0.4233 & 1.14 & -0.0585 & -0.10 & 0.6199 & 1.52 \\
\hline$R O A$ & $?$ & 0.9392 & 0.66 & 2.2693 & 0.82 & 1.2487 & 0.82 \\
\hline QUICK & $?$ & -0.1244 & $-1.89 * *$ & -0.2697 & -0.84 & -0.1234 & $-1.86^{*}$ \\
\hline CATA & $?$ & -0.3516 & -0.51 & -1.1772 & -1.05 & -0.5238 & -0.74 \\
\hline$C F O$ & $?$ & 2.1973 & 1.57 & 1.5395 & 0.54 & 2.5762 & 1.79 \\
\hline Pseudo $R^{2}$ & & $14.86 \%$ & & $12.58 \%$ & & $16.64 \%$ & \\
\hline Nobs. & & 130 & & 55 & & 128 & \\
\hline
\end{tabular}

Table 4. Audit fees and specialist auditor choice

\begin{tabular}{|c|c|c|c|c|c|c|c|}
\hline \multirow[b]{3}{*}{ Variables } & \multirow[b]{3}{*}{ Pred. Sign } & \multicolumn{2}{|c|}{ (1) } & \multicolumn{2}{|c|}{$(2)$} & \multicolumn{2}{|c|}{ (3) } \\
\hline & & \multicolumn{2}{|c|}{ Post-Post ${ }^{1}$} & \multicolumn{2}{|c|}{ Internal control deficiencies } & \multicolumn{2}{|c|}{$\begin{array}{c}\text { No internal control } \\
\text { deficiencies }\end{array}$} \\
\hline & & Coef. & $t$-value ${ }^{2}$ & Coef. & $t$-value & Coef. & $t$-value \\
\hline CONSTANT & & 14.0100 & $64.03 * * *$ & 14.1058 & $40.30 * * *$ & 13.9543 & $48.21 * * *$ \\
\hline EXPERT & + & 0.3417 & $2.80 * * *$ & 0.6228 & $3.02 * * *$ & 0.2162 & $1.39^{*}$ \\
\hline$S A L E G R W$ & - & -0.4377 & $-1.56^{*}$ & -0.7397 & $-1.74 * *$ & -0.3311 & -0.87 \\
\hline$L E V$ & + & 0.6608 & $2.56^{* * *}$ & 1.1523 & $2.11 * *$ & 0.6657 & $2.13 * *$ \\
\hline LOSS & + & 0.1472 & 0.92 & 0.0984 & 0.40 & 0.0148 & 0.07 \\
\hline$R O A$ & - & 1.4956 & $2.44 * * *$ & 0.6899 & 0.77 & 2.3284 & $2.76^{* * *}$ \\
\hline QUICK & - & -0.0778 & $-3.16^{* * *}$ & -0.0532 & -1.12 & -0.0832 & $-2.83 * * *$ \\
\hline CATA & - & -0.0954 & -0.33 & -1.1943 & -0.40 & -0.0090 & -0.03 \\
\hline$M A$ & + & -0.1163 & -0.72 & -0.3148 & -1.14 & 0.0032 & 0.02 \\
\hline$L S U B$ & + & 0.6527 & $8.38^{* * *}$ & 0.4386 & $3.40 * * *$ & 0.7244 & $7.29 * * *$ \\
\hline$C F O$ & + & -0.8653 & -1.28 & -0.4424 & -0.46 & -1.5198 & $-1.60 *$ \\
\hline Adj. $R^{2}$ & & $24.99 \%$ & & $26.93 \%$ & & $25.79 \%$ & \\
\hline Nobs. & & 353 & & 128 & & 225 & \\
\hline
\end{tabular}

\section{Conclusions}

Previous studies (Ashbaugh-Skaife et al., 2007; Grothe et al., 2007a; Grothe et al., 2007b) have indicated that companies with material deficiencies frequently find it necessary to restate earnings, and auditor changes are associated with an increased incidence of restatements (Romanus et al., 2008; Lazer et al., 2004; Lys \& Watts, 1994). However, previous research did not take into account the fact that internal control failures are frequently accompanied by auditor changes, because the quality of internal control systems is associated with the choice of external auditor. This study investigated the association between internal control situations and external auditor selections, providing evidence that companies with material deficiencies in internal control system are significantly more likely than companies with sound internal controls to terminate their auditors. Specifically, post-SOX misstatements of post-SOX restatements significantly affect the association between the probability of auditor changes and material deficiencies in internal control system. Our results also indicate that companies with material deficiencies in internal control system are less likely to change to specialist auditors, particularly when such companies suffer post-SOX misstatements of post-SOX restatements. Finally, our empirical results provide evidence that when companies with material deficiencies in internal control system hire specialist auditors to restore their internal control situations, they are likely to pay higher audit fees to do so. 


\section{Acknowledgements}

We gratefully acknowledge the financial support from Providence University (PU101-11100- A01).

\section{References}

Ashbaugh-Skaife, H., Collins, D., \& Kinney, W. (2007). The discovery and reporting of internal control deficiencies prior to SOX-mandated audits. Journal of Accounting and Economics, 44, 166-192. http://dx.doi.org/10.1016/j.jacceco.2006.10.001

Balsam, S., Krishnan, J., \& Yang, J. S. (2003). Auditor industry specialization and earnings quality. Auditing: A Journal of Practice \& Theory, 22, 71-97. http://dx.doi.org/10.2308/aud.2003.22.2.71

Deloitte \& Touche LLP, Ernst \& Young LLP, KPMG LLP, and PricewaterhouseCoopers LLP (DEKP). (2004). Perspectives on internal control reporting: A resource for financial market participants.

Doyle, J., Ge, W., \& Mcvay, S. (2007a). Determinants of Weaknesses in Internal Control Over Financial Reporting. Journal of Accounting and Economics, 193-223. http://dx.doi.org/10.1016/j.jacceco.2006.10.003

Doyle, J., Ge, W., \& Mcvay, S. (2007b). Accruals Quality and Internal Control over Financial Reporting. The Accounting Review, 85, 1141-1170. http://dx.doi.org/10.2308/accr.2007.82.5.1141

Elder, R., Zhang, Y., Zhou, J., \& Zhou, N. (2009). Internal control weaknesses and client risk management. Journal of Accounting, Auditing and Finance, 24, 543-579.

Ferguson, A. C., Francis, J. R., \& Stokes, D. J. (2006). What matters in audit pricing: Industry specialization or

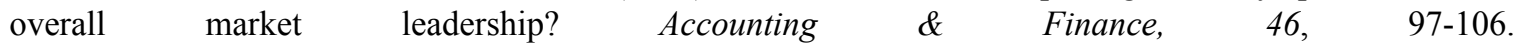
http://dx.doi.org/10.1111/j.1467-629X.2005.00152.x

Francis, J. R., Reichelt, K., \& Wang, D. (2005). The pricing of national and city-specific reputations for industry expertise in the U.S. audit market. The Accounting Review, 80, 113-136. http://dx.doi.org/10.2308/accr.2005.80.1.113

Ge, W., \& McVay, S. (2005). On the disclosure of material weaknesses in internal control after the Sarbanes-Oxley Act. Working Paper, University of Michigan.

Grothe, M., Goodwin, J., Iandera, O., Laurion, H., \& Freeland, J. (2007a). The materially weak. Yellow Card Trend Alert. Glass Lewis \& Co., LLC.

Grothe, M., Saban, J., Plachecki, M., Lee, R., \& Post, B. (2007b). The errors of their ways. Yellow Card Trend Alert. Glass Lewis \& Co., LLC.

Hammersley, J., Myers, L., \& Shakespeare, C. (2008). Market reactions to the disclosure of internal control weaknesses and to the characteristics of those weaknesses under Section 302 of the Sarbanes-Oxley Act of 2002. Review of Accounting Studies, 13, 141-165. http://dx.doi.org/10.1007/s11142-007-9046-z

Hogan, C. E., \& Wilkins, M. S. (2008). Evidence on the audit risk model: Do auditors increase audit fees in the presence of internal control deficiencies? Contemporary Accounting Research, 25, 219-242. http://dx.doi.org/10.1506/car.25.1.9

Hoitash, R., Hoitash, U., \& Bedard, J. C. (2008). Internal control quality and audit pricing under the Sarbanes-Oxley Act. Audit: A Journal of Practice \& Theory, 27, 105-126. http://dx.doi.org/10.2308/aud.2008.27.1.105

Hoitash, R., Markelevich, A., \& Barragato, C. A. (2007). Auditor fees and audit quality. Managerial Auditing Journal, 22, 761-786. http://dx.doi.org/10.1108/02686900710819634

Kennedy, P. (1998). A Guide to Econometrics (4th ed.). Cambridge, MA: Massachusetts Institute of Technology Press.

Krishnan, G. V. (2003). Does big 6 auditor industry expertise constrain earnings management? Accounting Horizons(Supplement), 17, 1-16. http://dx.doi.org/10.2308/acch.2003.17.s-1.1

Krishnan, G. V., \& Visvanathan, G. (2007). Reporting internal control deficiencies in the post-Sarbanes-Oxley era: The role of auditors and corporate governance. International Journal of Auditing, 11, 73-90. http://dx.doi.org/10.1111/j.1099-1123.2007.00358.x

Lazer, R., Livnat, J., \& Tan, C. E. L. (2004). Restatements and accruals after auditor changes. Working paper, New York University.

Lys, T., \& Watts, R. L. (1994). Lawsuits against auditors. Journal of Accounting Research, 32, 65-93. 
http://dx.doi.org/10.2307/2491440

Raghunandan, K., \& Rama, D. (2006). SOX Section 404 material weaknesses disclosures and audit fees. Auditing: A Journal of Practice \& Theory, 25, 99-114. http://dx.doi.org/10.2308/aud.2006.25.1.99

Romanus, R. N., Maher, J. J., \& Fleming, D. M. (2008). Auditor industry specialization, auditor changes, and accounting restatements. Accounting Horizons, 22, 389-413. http://dx.doi.org/10.2308/acch.2008.22.4.389 